\title{
Chronic Toxicity of Ectomethrin: A Biochemical and Histological Study
}

\section{Original Article}

\author{
Hanan S. Mahmoud ${ }^{1}$ and Amel I. Othman ${ }^{2}$
}

Department of Zoology, Faculty of Science, ${ }^{1}$ Beni-Suef University, ${ }^{2}$ Cairo University, Egypt

\begin{abstract}
Introduction: Ectomethrin (ECM) a synthetic pyrethroid, has broad spectrum use in agriculture, domestic and veterinary medical applications. Its prolonged and indiscriminate use has both acute and chronic toxicity in non-target species including humans.

Aim of the work: To evaluate the toxic effects of ECM inhalation in rats, and its recovery after stopping the treatment.

Materials and Methods: A total of forty Wistar male albino rats were divided into four groups. First group served as control group and received no treatment. Second group; ECM45 was administered $0.3 \mathrm{ml} / \mathrm{kg} /$ day of ECM daily by inhalation for 45 days. Third group; ECM90 group was administered the same ECM dose for 90 days. The forth group is the recovery group; Rec30 was administered the same dose of ECM by inhalation for 90 days, then the inhalation was stopped and the animals were left to recover without any treatment for another 30 days. At the end of the experiment, blood and tissue samples were obtained.

Results: ECM-intoxication revealed significant alterations in the oxidative stress parameters, malondialdehyde and superoxide dismutase in all treated groups. However, these alterations were attenuated in the recovery group and tended to approach normal levels. Histopathologically, ECM-intoxication revealed dramatic changes in liver and lung tissues and induced minor changes in the heart. The liver showed ballooning degeneration, focal lymphocytic aggregation, pyknotic nuclei, dilated central vein, collapsed sinusoidal spaces, focal necrosis and vascular degeneration. The lung revealed marked respiratory inflammation and focal necrosis and the heart showed myocardial hypertrophy. The recovery group had less severe complications in investigated tissues.

Conclusion: ECM inhalation resulted in severe biochemical and histological alterations that were attenuated after stopping inhalation.
\end{abstract}

Received: 23 December 2018, Accepted: 17 February 2019

Key Words: Ectomethrin, heart, histopathology, liver, lung, oxidative stress.

Corresponding Author: Amel Irahim Othman, PhD, Department of Zoology, Faculty of Science, Cairo University, Giza, Egypt, Tel.: +20 1115552315, E-mail: aimohamed@sci.cu.edu.eg

ISSN: $1110-0559$, Vol. 42, No. 3

\section{INTRODUCTION}

Synthetic pyrethroid insecticides are photo-stable analogs of the natural pyrethrins of botanical origin ${ }^{[1]}$. They are among the most commonly used pesticides for controlling agricultural and indoor $\operatorname{pests}^{[2,3,4,5]}$. Recently, the use of pyrethroids has been increasing because restrictions have been placed on many of the organophosphorus insecticides ${ }^{[6,7,8]}$. Although the specific mechanisms underlying their activity are incompletely understood, natural pesticides are considered the safest based on their target specificity and rapid degradation in the environment ${ }^{[9,10]}$. Pyrethroids have been generally classified into two subclasses, Type I which have not cyano-group, such as permethrin, while most of Type II have it such as cypermethrin ${ }^{[1]}$. In rats, Type I induced hyper-excitation, aggressiveness, hyper-aesthesia and whole body tremors ${ }^{[11]}$. Among Type I Pyrethroids, ECM is a highly active insecticide against a broad range of pests including lice, ticks, fleas, mites, and other arthropods.
It acts on the nerve cell membrane to disrupt the sodium channel current by which the polarization of the membrane is regulated. Delayed repolarization and paralysis of the pests are the consequences of this disturbance ${ }^{[4,10]}$. Also, ECM inhibits various adenosine tri-phosphatases including the calcium magnesium-ATPase in nervous tissue ${ }^{[11]}$. The disrupted membrane polarization and calcium homeostasis are directly linked to oxidative stress and many other cellular dysfunctions of vital organs as reported by Yang et al. $(2018)^{[12]}$.

Most simply, oxidative stress can be defined as the imbalance between the production of free radicals capable of causing lipid peroxidation (LPO) and alter the body's antioxidant defense system ${ }^{[13]}$. Reactive oxygen species (ROS), such as superoxide anions, hydroxyl radicals, and $\mathrm{H}_{2} \mathrm{O}_{2}$, enhance oxidative processes and produce lipid peroxidative damage of cell membranes. Malondialdehyde (MDA) is a well-known byproduct of LPO and its formation indicates oxidative cellular damage following exposure to a xenobiotic compound. Moreover, among 
the cellular cyto-protective molecules that may protect against oxidative stress is superoxide dismutase (SOD). It catalyzes the conversion of the superoxide anion into oxygen and hydrogen peroxide, and the latter becomes oxygen and water via catalase activity ${ }^{[14]}$.

Therefore, the present study aimed to evaluate the cytotoxic effect of ECM inhalation in rats, and the recovery effect after stopping of ECM inhalation. This effect was studied by the investigation of the histopathologic profile of rat vital tissues, liver, lung and heart, as well as, the oxidative stress parameters, MDA level and SOD activity.

\section{MATERIAL AND METHODS}

\section{Chemicals}

Commercial formulation of ECM was obtained from Plants Protection Research Institute, Dokki, Giza, Egypt. Chemicals and pure reagents were purchased from Sigma.

\section{Median lethal dose (LD50) estimation of ECM}

Median lethal dose of ECM was estimated by inhalation method of different doses of 10-100 ml/kg.b.wt to Wistar male albino rats. Rats were divided into five groups $(n=5)$ after starving the animals for 24 hours according to Lorke $(1983)^{[15]}$. The animals were observed from possible manifestation of physical signs of toxicity such as weight loss, decreased respiration and finally death. The number of deaths were taken in each group within 24 hours. The LD50 was calculated as the geometrical means of the maximum dose producing $0 \%$ (a), and the minimum dose producing $100 \%$ mortality (b). LD50 $=\sqrt{\mathrm{ab}} ;(\mathrm{a}=10, \mathrm{~b}=90$, $\mathrm{LD} 50=\sqrt{10 \times 90}=30$.

\section{Experimental design}

Forty healthy adult male Wistar albino rats of similar age (3-4 months), weighing 120-150 g, were obtained from local veterinary research institute (Beni-Suef, Egypt). The rats were housed in groups of 10 rats per cage. They were acclimatized for one week before starting the experiment. The animals were maintained in a room under standard or hygienic conditions of controlled temperature $\left(25^{\circ} \mathrm{c}\right)$, relative humidity (60), 12-h day/night cycle, fed with standard rat pellet and allowed drinking water ad-libitum throughout the experimental period. The study is adapted to bioethics of Egyptian Scientific Research Academy that coincide well with the National Institute of Health (NIH) Guidelines.

The rats were divided into four groups $(n=10)$, first group served as control group and received no treatment. The second group (ECM45) was given $0.3 \mathrm{ml} / \mathrm{kg} / \mathrm{day}$ (1/10 LD50) of ECM daily by inhalation for 45 days. Third group (ECM90) was given the same dose of ECM daily by inhalation for 90 days. The forth group (Rec30) served as recovery group was administered the same dose of ECM daily by inhalation for 90 days, then stopped the inhalation and left to recover without any treatment for another 30 days. The control animals were sacrificed simultaneously with each of the treated groups.

\section{Biochemical study}

SOD activity was determined according to Das et al., $(1993)^{[16]}$. MDA level was determined according to RuizLarrea et al. $(1994)^{[17]}$.

\section{Histological study}

Liver, lung and heart tissues were dissected out and their tissue samples were fixed in neutral buffer formalin (NBF) for $24 \mathrm{~h}$, processed by using a graded ethanol series, and embedded in paraffin. Then $5 \mu \mathrm{m}$ thick sections were obtained and stained by haematoxylin and eosin for light microscopic investigations ${ }^{[18]}$.

\section{Statistical analysis}

The data were expressed as means \pm SEM Data were analyzed by analysis of variance (ANOVA) followed by the Duncan multiple range test when the F-test was significant $(P<0.001)$. All analyses were performed using the Statistical Package for Social Sciences (SPSS) software in a PC-compatible computer.

\section{RESULTS}

ANOVA revealed significant alterations in the level of MDA and activity of SOD between all groups throughout the experimental period. Daily ECM inhalation showed a significant increase $(P<0.001)$ in the level of MDA of all treated groups. However, this increase was attenuated by the stopping of ECM inhalation for 30 days in the recovery group (Figure 1). A significant decrease $(P<0.001)$ in SOD activity was obtained in all treated group. This decrease was exaggerated in ECM90 and then nearly returned to its normal activity after stopping ECM inhalation for 30 days in the recovery group (Figure 2).

Light microscopic picture of normal liver section showed hepatocytes arranged in thin plates, with one/ two cell thick, compressing narrow sinusoidal spaces in between. The hepatocytes have eosinophilic cytoplasm containing one or two large rounded nuclei with prominent nucleoli (Figure 3a). Hepatotoxic picture of ECM90 appeared with disturbed architecture, ballooning degeneration or vacuolated liver cells, focal lymphocytic aggregation, pyknotic nuclei, dilated central vein, collapsed sinusoidal spaces and vascular degeneration, in addition to local cell death resulting in multiple-foci of necrosis (Figure $3 \mathrm{~b} \& \mathrm{c}$ ). This dramatic degenerative picture was greatly ameliorated after stopping of ECM treatment for 30 days in the recovery group (Figure 3d). Lung sections of the control group showed simple normal respiratory epithelium with columnar and ciliated cells containing few goblet cells (Figure 4a). The smooth muscle fibers are the most prominent feature of the bronchiole and are disposed in a spiral manner encircling the mucosal and sub-mucosal layers of the bronchi. Each respiratory bronchiole divides further into several long passages called alveolar ducts, that breakdown into numerous thin walled alveolar sacs and alveoli. Surrounding each alveolus is a rich network of pulmonary capillaries for gas exchange. ECM90 
showed thick walled alveoli, necrotic hyaline cartilage and vascular degeneration. Moreover, marked respiratory inflammation was observed as peribronchial and perivascular lymphocytic aggregations (Figures $4 b \& c$ ). The recovery group showed less severe complications in the respiratory tissue (Figure 4d). Normal myocardial cells are seen to contain one or two elongated centrally located nuclei and extensive cytoplasm which branches to give the appearance of a continuous three-dimensional network (Figure 5a). ECM90 revealed hypertrophic myocardium and elongated hyperchromatic nuclei, where the muscle fibers appeared to be enlarged with densely stained nuclei (Figure $5 b$ ). The heart of the recovery group showed nearly normal cardiac architecture (Figure $5 \mathrm{c} \& d$ ).

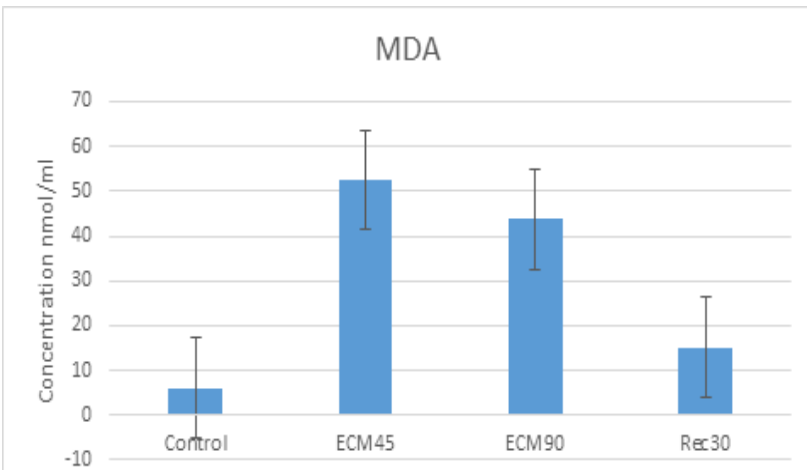

Fig. 1: Effect of ECM inhalation on the serum MDA level. $(*)$ : highly significant $(p<0.001)$.

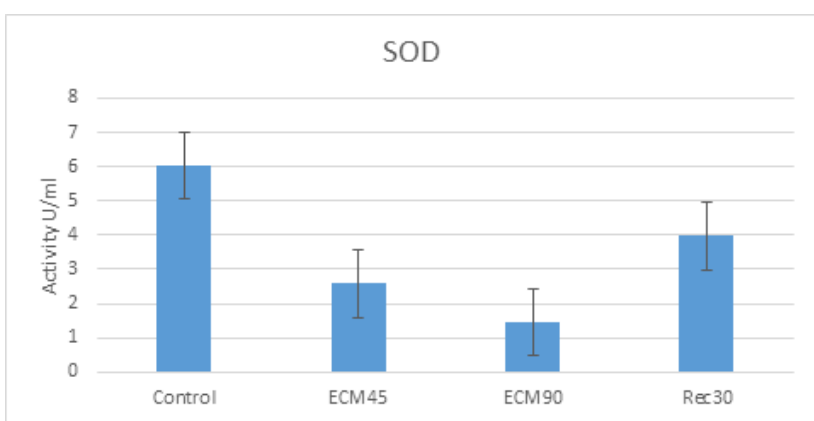

Fig. 2: Effects of ECM inhalation on the serum SOD activity. $(*)$ : highly significant $(p<0.001)$.

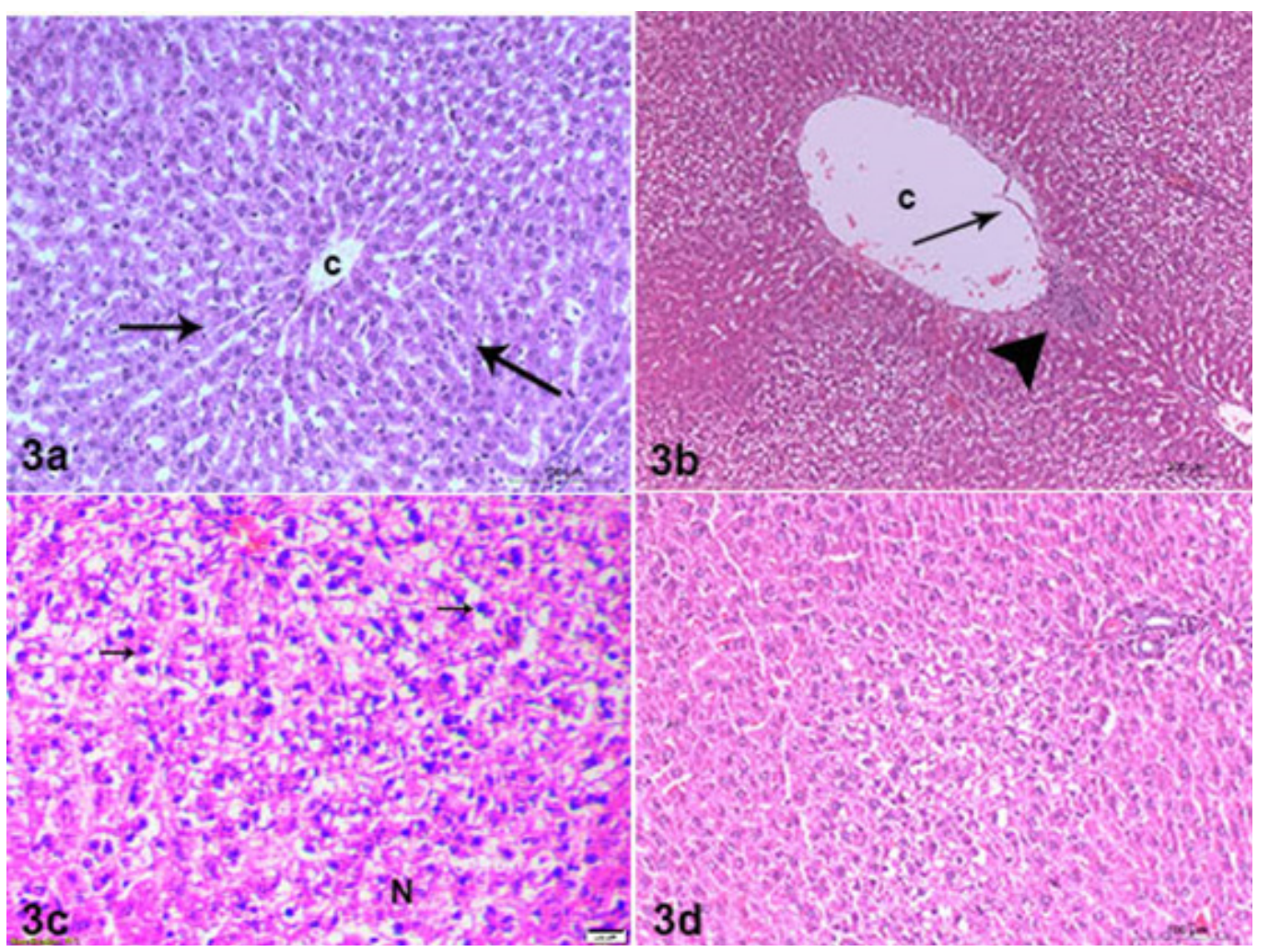

Fig. 3: Photomicrograph of rat liver, a) showing normal hepatic architecture, central vein (c), hepatic plates (arrows), scale bar $=100 \mu \mathrm{m}$. b) ECM90 group showing dilated central vein (c), vascular degeneration (arrow), focal inflammation (arrow head), scale bar $=200 \mu \mathrm{m}, \mathrm{c}$ ) higher magnification of ECM90 group shows focal necrosis $(\mathrm{N})$, pyknotic nuclei (arrows), scale bar $=20 \mu \mathrm{m}$. d) Recovery group showing the most of hepatocytes regain its normal appearance, scale bar $=100 \mu \mathrm{m}, \mathrm{H} \& \mathrm{E}$ stain. 


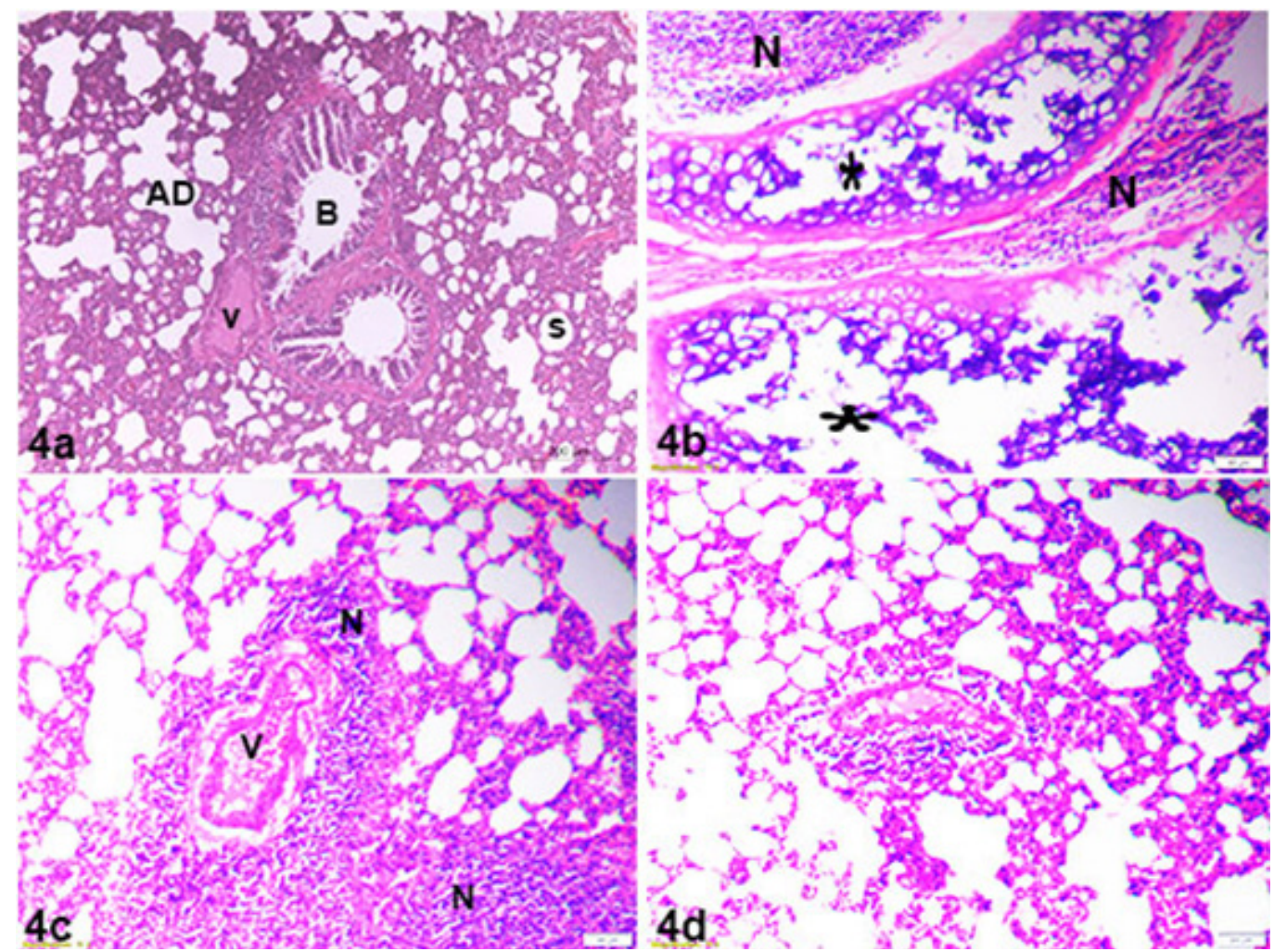

Fig. 4: Photomicrograph of rat lung, a) showing normal architecture of lung tissue, bronchiole(B), vein (v), alveolar duct (AD), alveolar sac (s), scale bar = $200 \mu \mathrm{m} . \mathrm{b} \& \mathrm{c})$ ECM90 group showing focal necrosis of hyaline cartilage (Asterisk), focal inflammation $(\mathrm{N})$, vascular degeneration $(\mathrm{v})$, scale bars $=50 \mu \mathrm{m}$. d) Recovery group showing mild degenerative changes, scale bar $=50 \mu \mathrm{m}, \mathrm{H} \& \mathrm{E}$ stain.

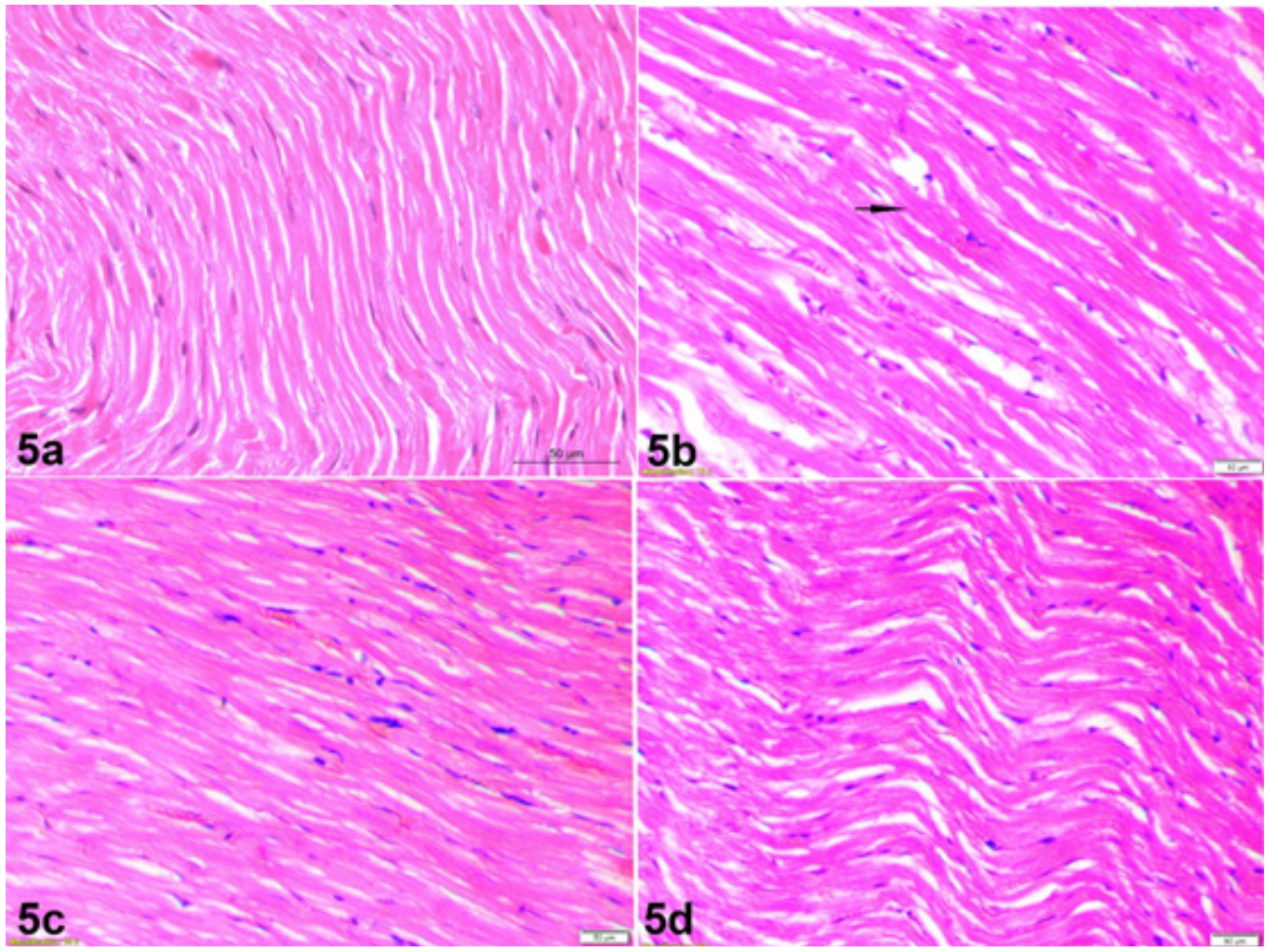

Fig. 5: Photomicrograph of rat heart, a) showing normal myocardial architecture, scale bar $=50 \mu \mathrm{m}$. b) ECM90 group showing myocardial hypertrophy with elongated hyperchromatic nuclei (arrow), scale bar $=50 \mu \mathrm{m} . \mathrm{c} \& d$ ) Recovery group showing nearly normal myocardium, scale bars $=50 \mu \mathrm{m}, \mathrm{H} \& \mathrm{E}$ stain . 


\section{DISCUSSION}

Oxidative stress is a term commonly used to announce the imbalance between the concentrations of ROS and the anti-oxidative defense mechanisms of the body, besides, it played an important role in cytotoxicity in many in vivo and in vitro models ${ }^{[14]}$. The current study clearly showed that ECM exposure induced oxidative stress. This stress accompanied with increased generation of ROS and alteration of MDA level and SOD activity. MDA showed significant increase in both 45 days and 90 days treated groups $(p \leq 0.001)$ as compared with control group. Cypermethrin was also report to induce the level of MDA with a concomitant increase in $\operatorname{ROS}^{[19]}$. The increased level of MDA observed in ECM inhalation was also reported as a result of pyrethroid insecticides exposure by several authors ${ }^{[20-24]}$. The current value of SOD activity represent a significant decrease in ECM-intoxicated groups $(p \leq 0.001)$. This depletion in the enzyme activity was consistent with other studies which confirm the role of oxidative stress as a potential mechanism for pyrethroids induced cytotoxicity ${ }^{\mathrm{y}}[14$, $23,25,26]$. In the recovery group, MDA showed a significant increase $(p \leq 0.001)$ approaching its normal level obtained in control group, however, SOD revealed significant decrease $(p \geq 0.001)$ appearing higher than that of the intoxicated ones. These results may be suggested that the stopping of ECM inhalation strengthen the powerful capacity of internal antioxidant system to attenuate and minimize the level of MDA and induced the activity of SOD.

Giray et al. $(2001)^{[25]}$ reported that exposure to certain environmental pollutants such as pyrethroid resulted in continuous formation of ROS in the cells, which being harmful in excess production. The rat tissues under current investigation may be susceptible to oxidative damage resulting from ECM-inhalation which could act as renewable source of free radicals. This was significantly appeared in the histopathologic picture localized by light microscopic examination for ECM90 intoxicated group and recovery group. Varying degrees of moderate to severe toxic alterations in the liver, lung and heart of male albino rats were observed. These alterations were focal necrosis, lymphocytic aggregation and vascular degeneration in liver tissue. Similar results also were observer by Grewal, et al., (2010) ${ }^{[27]}$ who reported that oral cypermethrinadministration produced necrosis of hepatic cells, with pyknotic nuclei and dilated sinusoids. In addition, Mamun et al., (2014) $)^{[28]}$ reported that cypermethrin intoxication induced deleterious impact in the structure of the liver tissues ${ }^{[29,30]}$. In addition, fatty degeneration, vacuolation and necrosis of hepatocytes had been observed following the exposure of animals to different pyrethroid treatments ${ }^{[20-24]}$. In the lung tissue, the current microscopic study localized necrotic hyaline cartilage of the respiratory bronchioles, focal inflammation and vascular degeneration. These findings are in agreements with those obtained by Grewal, et al., (2010) ${ }^{[27]}$ who reported dose- and time-dependent histopathological alterations with congestion, hemorrhage, and thickening of inter-alveolar septa. Recently, in 2017,
Yang et al.. ${ }^{[10]}$ demonstrated that natural pyrethrins increase the production of ROS, reduce cell viability and enhance apoptosis in hepatic cells. In a study on the liver and lung of pyrethroid intoxicated mice, the authors concluded that these insecticides cause hazardous effects in nontargeted organisms through inhalation exposure ${ }^{[31]}$. The heart of the current study showed hypertrophic myocardial activity. Similarly, single administrated dose of pyrethroids induce hypertrophic alterations in rat heart as indicated by Kale et al., (1999) ${ }^{[20]}$. In a previous report on the heart tissue, it was shown that the lower dose of cypermethrin has no apparent adverse effect, but higher dose produced hemorrhages, disruption in branching structure with loss of striations, and early necrotic changes in the myocardium ${ }^{[27]}$. The author claimed that these changes observed in heart may suggest a prolonged harmful effect of cypermethrin. Consequently, it may be suggested that the effect of pyrethroid insecticides had a dose dependent effect.

From the present study, it may be concluded that ECM inhalation induces cytotoxic effects and oxidative stress on non-targeted organisms. Accordingly, it may be suggested that ECM produces a potential health risks accompanied with severe histopathologic alteration in the tissues of the most vital organs, liver, lung and heart. These resulting toxicity may be attenuated or minimized by the withdrawal effect of these environmental toxic compound.

\section{CONFLICT OF INTEREST STATEMENT}

There are no conflicts of interest.

\section{REFERENCES}

1. Bradbury S and Coats JR: Comparative toxicology of pyretheroid insecticides. Rev. Environ. Contam. Toxicol. 1989; 108: 133-77.

2. Casida JE and Quistad GB: Golden age of insecticide research: past, present, or future? Annu. Rev. Entomol. 1998; 43:1-16.

3. Soderlund DM, Clark JM, Sheets LP, Mullin LS, Piccirillo VJ, Sargent D, Stevens JT and Weiner ML: Mechanisms of pyrethroid neurotoxicity: implications for cumulative risk assessment. Toxicol. 2002; 171(1): 3-59.

4. Walters KB, Dodd ME, Mathias JR, Gallagher AJ, Bennin DA, Rhodes J, Kanki JP, Look AT, Grinblat Y and Huttenlocher A: Muscle degeneration and leukocyte infiltration caused by mutation of zebrafish fad24. Dev. Dynam. 2009; 238 (1): 86-99.

5. Hossain MM and Richardson JR: Mechanism of Pyrethroid Pesticide-Induced Apoptosis: Role of Calpain and the ER Stress Pathway. Toxicol Sci. 2011; 122(2): 512-525.

6. Oros DR and Werner I: Pyrethroid Insecticides: An Analysis of Use Patterns, Distributions, Potential Toxicity and Fate in the Sacramento-San 
Joaquin Delta and Central Valley. White Paper for the Interagency Ecological Program. SFEI Contribution 415. San Francisco Estuary Institute, Oakland, CA. 2005.

7. Calvert GM, Mehler LN, Rosales R, Baum L, Thomsen C, Male D, Shafey O, Das R, Lackovic $\mathrm{M}$ and Arvizu E: Acute pesticide-related illnesses among working youths, 1988-1999. Am. J. Public Health. 2003; 93: 605-610.

8. Kimata A, Kondo T, Ueyama J, Yamamoto K, Yoshitake J, Takagi K, Suzuki K, Inoue T, Ito Y, Hamajima N, Kamijima M, Gotoh M and Shibata E: Comparison of urinary concentrations of 3-phenoxybenzoic acid among general residents in rural and suburban areas and employees of pest control firms. Int. Arch. Occup. Environ. Health. 2009; 82: 1173-1178.

9. Wang X, Martínez MA, Dai M, Chen D, Ares I, Romero A, Castellano V, Martínez M, Rodríguez JL, Martínez-Larrañaga MR, Anadón A and Yuan Z: Permethrin-induced oxidative stress and toxicity and metabolism. A review. Environ Res. 2016; 149: 86-104.

10. Yang Y, Zong M, Xu W, Zhang Y, Wang B, Yang $\mathrm{M}$ and Tao L: Natural pyrethrins induces apoptosis in human hepatocyte cells via Bax- and Bcl-2mediated mitochondrial pathway. Chem. Biol. Interact. 2017; 262 (25): 38-45.

11. Beasley CM, Hamilton SH, Crawford AM, Dellva MA, Tollefson GD, Tran PV, Blin O and Beuzen JN: Olanzapine versus haloperidol: acute phase results of the international double-blind olanzapine trial. Eur. Neuropsychopharmacol. 1997; 7 (2): 125-37.

12. Yang JS, Symington S, Clark JM and Park Y: Permethrin, a pyrethroid insecticide, regulates ERK1/2 activation through membrane depolarization-mediated pathway in HepG2 hepatocytes. Food Chem Toxicol. 2018; 121: 387-395.

13. Abdollahi M, Ranjbar A, Shadnia S, Nikfar S and Rezaie A: Pesticides and oxidative stress: A review. Med Sci Monitor. 2004; 10: 141-147.

14. Hu F, Li L, Wang C, Zhang Q, Zhang X and Zhao $\mathrm{M}$ : Enantioselective induction of oxidative stress by permethrin in rat adrenal pheochromocytoma (PC12) cells. Environ. Toxicol. Chem. 2009; 29 (3): 683-690.

15. Lorke D: A new approach to practical acute toxicity testing. Arch Toxicol. 1983; 54 (4): 275-87.

16. Das SR, Bhowmik MK, Samanta G and Sarkar S: Toxicopathologic effects of autoclaved dhaincha (Sesbania aculeata) seed-meal in broiler chicks.
Indian J. Anim. Sci. 1993; 63 (3): 329-333.

17. Ruiz-Larrea MB, Leal AM, Liza M, Lacort M and de Groot $\mathrm{H}$ : Antioxidant effects of estradiol and 2-hydroxyestradiol on iron-induced lipid peroxidation of rat liver microsomes. Steroids. 1994; 59 (6): 383-388.

18. Bancroft JD and Gamble M: Theory and Practice of Histological Techniques, 5th ed., Endinburgh: Churchill, Livingstone. 2002.

19. Muthuviveganandavel V, Muthuraman P, Muthu S and Srikumar K: A study on low dose cypermethrin induced histopathology, lipid peroxidation and marker enzyme changes in male rat. Pestic. Biochem. Physiol. 2008; 91:11-16.

20. Kale M, Rathore N, John S, Bhatnagar D, Nayyar SS and Kothari V: The Protective Effect of Vitamin E in Pyrethroid-induced Oxidative Stress in Rat Tissues. J. Nutr. Environ. Med. 1999; 9 (4): 281-287.

21. Aldana L, Tsutsumi V, Craigmill A, Silveira MI and Gonzalez de Mejia E: Alpha-Tocopherol modulates liver toxicity of the pyrethroid cypermethrin. Toxicol. Lett. 2001; 125 (1-3): 107-16.

22. Yavaşoğlu A, Sayim F, Uyanikgil Y and Yavaşoğlu ÜK: The pyrethroid cypermethrin-induced biochemical and histological alterations in rat. J. health sci. 2006; 52 (6): 774-780.

23. Sankar P1, Telang AG and Manimaran A: Protective effect of curcumin on cypermethrininduced oxidative stress in Wistar rats. Exp. Toxicol. Pathol. 2012; 64 (5): 487-93.

24. Bhushan B, Saxena PN and Saxena N: Biochemical and histological changes in rat liver caused by cypermethrin and beta-cyfluthrin. Arh. Hig. Rada. Toksikol. 2013; 64 (1): 57-67.

25. Giray B, Gurbay A and Hincal F: Cypermethrininduced oxidative stress in rat brain and liver is prevented by vitamin E or allopurinol. Toxicol. Lett. 2001; 18: 139-146.

26. Issam $C$, Intissar $G$, Fatma B, Yahia HM, Samir H, Zohra H and Hassen B: Oxidative Stress, Biochemical and Histopathological Alterations in the Liver and Kidney of Female Rats Exposed to Low Doses of Deltamethrin (DM): A Molecular Assessment. Biomed. Environ. Sci. 2012; 25 (6): 672-683.

27. Grewal kk, Sandhu GS, Kaur R, Brar RS and Sandhu HS: Toxic Impacts of Cypermethrin on Behavior and Histology of Certain Tissues of Albino Rats. Toxicol. Int. 2010; 17 (2): 94-98.

28. Mamun MAA, Illa IJ, Haque KMF and Ferdousi Z: Histological study of the effects of cypermethrin on liver and kidney tissues of mice model. IOSRJPBS. 2014; 9 (5): 121-128. 
29. Biernacki B, Wlodarczk B, Minta $M$ and Jurzkiewicz T: Influence of cypermethrcin on pregnancy and fetal development in rabbits. Med. Weter. 1995; 51: 31-3.

30. Shah MA, Gupta PK and Tandon HK: Effect of permethrin: A synthetic pyrethroid on pentobarbitone induced sleeping time and hepatic microsomal constituents in mice. Ind. J. Toxicol. 1996; 3: 19-23.

31. Sheikh N, Javed S, Asmatullah A, Ahmad KR, Abbas $\mathrm{T}$ and Iqbal $\mathrm{J}$ : Histological Changes in the Lung and Liver Tissues in Mice Exposed to Pyrethroid Inhalation. WJST. 2014; 11 (10): 318-23. 


\section{الملخص العربى}

\section{السمية المزمنة للاكتوميثيرين: دراسة بيوكيميائية ونسيجية \\ 'حنــــان سيد محمود و 'أمســـل إبراهيم عثمان}

قسم علم الحيوان ـ كلية العلوم - جامعة بني سويف'، قسم علم الحيوان ـ كلية العلوم - جامعة القاهرة' إنمان

المقدمة: الاكتوميثيرين هو مركب بيريثرويد صناعي، له استخدام واسع النطاق في مجال الزر اعة ، و التطبيقات الطبية المنزلية و البيطرية و استخدامه لفتر ات طويلة وبشكل عشو ائي له سمية حادة ومزمنة في الأنو اع غير المستهدفة بما فيها

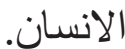

الههف من البحث: تهذف هذه الدر اسة إلى كثف الآثار السامة التي يسببها استشاق الاكتوميثيرين على انسجة الجرذان أثناء وبعد التوقف عن المعاملة.

مواد وطرق البحث: تم تقسيم أربعين من ذكور الجرذان البيضاء إلى أربع مجموعات: لم تتلق المجموعة الضابطة أي علاج. تم معماملة المجموعات الثناث الاخرى باستنشاق الاكتوميثيرين يوميا بجر عة تعادل 0.0.3 ملجم/ كجم. المجمو عة الثانية دام الاسستنشاق خلالها لمدة 0؛ يوما، المجموعة الثالثة دام الاستنشاق خلالها لمدة . 9 بومًا. أما مجمو عة الر ابعة (مجمو عة التعافي) فقد تم الاستنشاق خلالها لمدة • 9، ثم تم إيقاف الاستنشاق وترك الحيو انات لتتعافى دون أي علاج لمدة • ب يومًا أخرى. وفي نهاية التجربة، تم الحصول على عينات الدم والأنسجة. النتائج: بالنسبة إلى مجمو عات استنشاق الاكتوميثيرين أظهرت الدر اسة البيوكيميائية زيادة كبيرة في مستوى الدهون و انخفاض ملحوظ في نشاط انزيم السوبر اكسيد دسميوتيز. بينما اظهرت مجموعة التعافي تغيرات أقل حدة في هذا الثأن. أما بالنسبة للار اسة النسيجية، فقد أظهرت مجمو عات الاكتو ميثثيرين حدوث تغير ات كبيرة في أنسجة الكبد و الرئة مع إحدث تغيير ات طفيفة في عضلة القلب. بالنسبة للكبد فقد شوهدت خلاياة وقد تحلل بعضها وازدادت الفجوات في البعض الآخرمع ظهور التهاب بؤري وتهنك في الاوعية الدموية وأظهرت الرئة التهاباً حادا في الجهاز التنفسي و تحلل لبعض الخلايا. هذا وقد اظهرت عضلة القلب تضخما في أليافها. بينما اظهرت مجمو عة التعافي مضاعفات أقل حدة في الأنسجة التي تم فحصها. الاستنتاج: تشير هذه النتائج إلى الأخطار التي يسبيها الاستخدام المكثف للإكتو ميثيرين و التي ربما تتحسن بشكل ملحوظ بعد التوقف عن استخدامة. 